Acta Botanica Brasilica - 30(3): 495-507. July-September 2016. doi: 10.1590/0102-33062016abb0192

\title{
Fruits and frugivores of the Brazilian Cerrado: ecological and phylogenetic considerations
}

\author{
Marcelo Kuhlmann ${ }^{1 *}$ and José Felipe Ribeiro
}

Received: June 8, 2016

Accepted: August 28, 2016

\begin{abstract}
Knowing the morphological and phylogenetic patterns of fruits of a plant community may elucidate plant-frugivore interactions, and analysis of dispersal syndromes is a practical approach to understanding these mutualisms. We investigated different zoochorous fruits and frugivorous animals among Cerrado formations (forest, savanna and grassland), mapped dispersal syndromes on a Cerrado angiosperm phylogeny and tested for phylogenetic signal. For a core region in Cerrado, we found that, among almost a thousand fruit species and 258 fruit-eating vertebrates, $60 \%$ of the fruits had an ornithochorous syndrome and that $70 \%$ of the frugivores were birds. Most fruit and frugivorous species $(\sim 80 \%)$ inhabit forest formations, but many of them also occurred in more than one Cerrado formation. The zoochorous syndromes were found to have little phylogenetic signal, with many plant families exhibiting more than one fruit syndrome, and with ornithochory being widely distributed throughout the phylogeny. Our results suggest that plant-frugivore interactions tend to be evolutionarily labile in this Neotropical region, although birds have had a prominent role in fruit evolution. Furthermore, we found that all three Cerrado formations seem to be interrelated in maintaining functional stability of the plant-frugivore mutualisms in the Cerrado biome.
\end{abstract}

Keywords: Cerrado biome, diaspores, dispersal syndromes, forest, fruit-eating animals, grassland, plant-frugivore interactions, phylogenetic signal, savanna

\section{Introduction}

Plant-frugivore interactions are vital for the natural regeneration of plants that depend on animals for seed dispersal (Jordano 2000; Jordano et al. 2011). There is considerable evidence that this mutualism has played an important role in the evolutionary diversification of the plants and animals involved (Herrera 1985; Eriksson et al. 2000; Tiffney 2004; Eriksson 2008; Bolmgren \& Eriksson 2010), with plants selecting particular traits of their consumers in the same way that frugivores select particular traits of plant fruits, resulting in the coevolution of these organisms over tens of millions of years (Fleming \& Kress 2013). Fruits with fleshy tissues are an important food resources for a wide variety of animals, and the availability of fruit in a given location can influence the abundance and diversity of these frugivores (Jordano \& Herrera 1995; Howe \& Westley 2009). Knowing the morphology of fruits and dispersal units in a plant community may help to better understand plant-animal interactions and the different plant colonization strategies (Galetti et al. 2006; Wiesbauer et al. 2008; Howe 2016).

\footnotetext{
${ }^{1}$ Institute of Biological Sciences, University of Brasilia, Campus Universitário Darcy Ribeiro, Asa Norte, Brasília - DF, 70910-900

${ }^{2}$ Embrapa Cerrados, BR 020 Km 18. Planaltina - DF, 73310-970

*Corresponding author: biomakp@gmail.com
} 
Different morphological traits of fruits and seeds, such as size, color, hardness, scent lures, amount and type of pulp reward, nutritive value and accessibility, have an influence on what kind of animal will be attracted, such as birds, non-flying mammals, bats or ants, and reflect different dispersal syndromes (Howe \& Smallwood 1982; Pijl 1982; Fleming et al. 1987). These "dispersal syndromes" (suites of traits of fruits or seeds) indicate the most likely dispersal agents and have potential usefulness in predicting the dispersal processes within a community at a given place and time (Howe 2016). However, it is important to emphasize that not all animals that eat fruits are good seed dispersers, and that different factors can influence these plant-frugivore mutualisms, such as fruit phenology, abundance of fruits and frugivorous animals, competition, predation, and weather conditions (Howe 2016). Animal traits, such as body size, behavior, method of locomotion, physiology, sensory capabilities and foraging tactics also can influence the selection of fruits and the effectiveness of seed dispersal (Janzen 1969; Wheelwright 1985; Galetti et al. 2013). Given these considerations, analysis of dispersal syndromes provides a practical approach to understand patterns of interactions within a community, assuming that the patterns we see today (phenotype) emerged from past selective pressures involving plants and frugivores (Fleming \& Kress 2013).

Since species are phylogenetically related, their morphological traits are not fully independent and so the amount of "phylogenetic signal" of traits needs to be measured statistically (Revell et al. 2008). Phylogenetic signal can be defined as the tendency for related species to resemble each other more than they resemble species drawn at random from the phylogenetic tree (Blomberg et al. 2003; Losos 2008). When the phylogenetic relationship of a group of organisms in a community is known, it is possible to investigate how strongly certain morphological and ecological characteristics are phylogenetically correlated, and if they form groups or niches that are strongly phylogenetically linked (Mouquet et al. 2012; Münkemüller et al. 2012). Knowing the phylogeny can also indicate the extent which closely related groups tend to establish similar mutualistic interactions (Rezende et al. 2007), such as those involving fruits and frugivores and their syndromes.

It is estimated that in tropical forests over $90 \%$ of woody plant species produce fruits that are eaten and dispersed by animals, and a high proportion of animals, especially birds and mammals, feed on fruits (Jordano 2000; Kissling et al. 2009). The natural world would be drastically affected by the absence of dispersing animals (Bello et al. 2015) and, depending on the vegetation type, natural regeneration cycles of most plants would be compromised (Janzen 1974; Howe et al. 1985), leading to local extinctions (Jordano et al. 2011). For the Brazilian Cerrado, a complex and megadiverse Neotropical biome with over 12,000 species of vascular plants (Ratter et al. 1997; Mendonça et al. 2008), it is estimated that about one third of all species, and 60\%-70\% of woody plant species, depend on animals for seed dispersal, and especially so for those of forest formations (Batalha \& Martins 2004; Gottsberger \& Silberbauer-Gottsberger 2006; Kuhlmann \& Ribeiro 2016). Human occupation and land use in the Cerrado have led to the loss of more than $50 \%$ of the original vegetation of the biome (Ratter et al. 1997; Sano et al. 2008), bringing consequences such as soil degradation, increase in invasive species and disruption of water cycles (Klink \& Machado 2005; Costa \& Pires 2010). A variety of human activities, such as forest fragmentation, hunting and extensive agriculture can impact seed dispersal mutualisms, affecting frugivores visitation, dispersal distance and seed removal (Markl et al. 2012; Sebastián-González et al. 2015). In this way, the preservation of biodiversity and persistence of the flora in biomes such as the Cerrado depend on the conservation and, when necessary, the restoration of seeddispersal processes and plant-animal interactions (Howe 2016).

The first step in conserving or restoring seed-dispersal processes is to understand what species of fruits and frugivores that interact within a given community. Since communities comprise groups of species that share certain similarities, both ecological and phylogenetic (Tilman 1988; Cavender-Bares et al. 2009), grouping plants according to their dispersal syndromes can help to make predictions about the seed-dispersal processes (Thomson et al. 2010; Fleming \& Kress 2013). Although a "syndrome" approach must be taken with care because of variation in place and time (Howe 2016), it promises to increase understanding of the reproductive strategies of angiosperms and, thereby, facilitate programs for the recovery of degraded areas, such as PLANAVEG (2014) in the Cerrado. The Cerrado biome is a complex mosaic of vegetation that comprises numerous different phytophysiognomies, which can be grouped into three main vegetative formations: forests, savannas and grasslands (Ribeiro \& Walter 2008), each of which contains species of flora and fauna with different survival strategies (Diniz et al. 2010). With this in mind, we investigated the proportions of different zoochorous syndromes and different groups of frugivores in these Cerrado formations. Moreover, we identified and mapped the distribution of these syndromes on a phylogeny of Cerrado angiosperms to test for the presence of phylogenetic signal. We intended to address the following questions: (i) What are the proportions of different zoochorous syndromes among angiosperms of the Cerrado? (ii) What is the proportion of bird and mammal species that feed on fruits in the Cerrado? (iii) Are there differences in the proportions of zoochoric syndromes and frugivore groups between forest, savanna and grassland formations? and (iv) Are zoochorous syndromes strongly conserved throughout angiosperms phylogeny or they are evolutionarily labile? 


\section{Materials and methods}

\section{Study area}

To address these questions we investigated species of the flora and fauna of the Federal District of Brazil, which is located in the core area of the Cerrado and is fairly representative of its characteristic vegetation types (Walter 2001), and plant (Cavalcanti \& Ramos 2001; Proença et al. 2001) and animals species (Fauna-DF 2016). The Federal District $\left(15^{\circ} 30^{\prime}-16^{\circ} 03^{\prime} \mathrm{S}\right.$ and $\left.47^{\circ} 18^{\prime}-48^{\circ} 17^{\prime} \mathrm{W}\right)$, has an area of $5,810 \mathrm{~km}^{2}$, an average altitude of $1,100 \mathrm{~m}$ and a seasonal tropical climate, with wet (October-March) and dry (April-September) seasons, and mean temperature varying between $12^{\circ} \mathrm{C}$ and $29^{\circ} \mathrm{C}$ (Silva et al. 2008). About $40 \%$ of this area is still conserved, with $16 \%$ as forest formations and $24 \%$ non-forest (savanna and grassland) (MMA 2015).

\section{Classification of fruits and frugivores}

An updated list of the native flora of the Federal District was obtained from the Flora of Brazil website (Forzza et al. 2016). The list of vertebrate species was compiled from literature on the fauna of the Federal District and of the entire Cerrado (Bagno \& Marinho-Filho 2001; MarinhoFilho et al. 2002; Aguiar et al. 2004; CTFB 2016; Fauna-DF 2016; Taxeus 2016). From these lists, zoochorous plants and fruit-eating animals were identified. Zoochorous plants were classified according to: dispersal syndrome (ornithochory, mastochory, chiropterochory, myrmecochory and "mixed"; Tab. 1, Fig. 1); diaspore size (diameter of the dispersal unit: of up to $10 \mathrm{~mm}, 10$ to $20 \mathrm{~mm}$ and $>20 \mathrm{~mm}$ ) and life form (trees, shrubs, herbs, lianas, epiphytes and mistletoes). The dispersion unit could be the whole fruit (drupes, berries), arillated seeds (in dry fruits) or part of the fruit (pulp) containing seeds (which included the fruits of the "mixed" syndrome). Information regarding syndromes and diaspore size was obtained from the literature (Barroso et al. 1999; Pinheiro \& Ribeiro 2001; Gottsberger \& Silberbauer-Gottsberger 2006; Lorenzi 2009; Kuhlmann \& Fagg 2012) and from field samples in Cerrado. Plant species were also organized phylogenetically by major lineages (basal angiosperm, monocots, basal eudicots, rosids and asterids) according to APG III (2009). The fauna list included vertebrates (birds, bats, and non-flying mammals) that partially or frequently feed on fruits (i.e., not only obligate frugivores), and were classified according to: taxonomy (family level), body size (small [<100 g] and large [> 100g]) and method of locomotion (volant, terrestrial, arboreal, arboreal/terrestrial; Fleming \& Kress 2013). Information regarding the traits of vertebrate animals was obtained from literature on Brazilian fauna (Marini et al. 1997; Leal \& Oliveira 2000; Reis et al. 2006; 2013; Gwynne et al. 2010; Bugoni et al. 2013; Wiki-Aves 2016). Both fruits and frugivores were also classified according to the vegetative formation of Cerrado they occupy (forest, savanna and grassland; see Ribeiro \& Walter 2008 for the vegetative formations definitions).

\section{Data analysis}

To compare the proportions and relationships among the measured variables (dispersal syndromes, angiosperm lineages, life forms, vegetation formations and animal traits) among the studied species, we used the G-test, in the package "DescTools" on R program with a significance level of $5 \%$. This test is suitable for comparing proportions and served to verify if the observed differences between the analyzed variables were significant or not (McDonald 2014).

To measure the phylogenetic signal of the zoochorous dispersal syndromes we used the lambda method (Pagel 1999), with the statistical package "phytools" (Revell 2012) on $\mathrm{R}$ program (version 3.2.1). This method generates a value of lambda ranging on a scale from 0 to 1 , where 0 corresponds to the absence of phylogenetic signal and 1 to the maximum phylogenetic signal (Münkemüller et al. 2012). To perform this test we first constructed a phylogenetic tree for the zoochorous angiosperm genera of the Cerrado using the MEGA program (version 6.0.6), with molecular sequence data obtained from the GenBank (2015). We used the chloroplast DNA sequences of "rbcl" and "matk", because they are frequently reported for angiosperms in GenBank. This phylogeny was constructed using Maximum

Table 1. Classification of zoochorous dispersal syndromes addressed in this study.

\begin{tabular}{|c|c|}
\hline Dispersal syndromes & Fruit and seed traits \\
\hline Ornithochory (Birds) & $\begin{array}{l}\text { Small fruits and seeds (up to } 10 \mathrm{~mm} \text { or } 20 \mathrm{~mm} \text { ), fleshy and colored (red, black, blue, purple) (Fig. 1A). Seeds with } \\
\text { aryl or mimetic and colored (Fig. 1B). }\end{array}$ \\
\hline Mastochory (Non-flying mammals) & $\begin{array}{l}\text { Large fruits and seeds (> } 20 \mathrm{~mm} \text { ), usually rigid, indehiscent (Fig. 1C); usually yellowish in color, strong odor and complete } \\
\text { maturation on the ground (Fig. 1D). }\end{array}$ \\
\hline Chiropterochory (Bats) & $\begin{array}{l}\text { Fleshy fruits, often greenish and inconspicuous color and strong odor (Fig. 1E); mature still attached to the mother } \\
\text { plant and out of the foliage (Fig. 1F). }\end{array}$ \\
\hline "Mixed" & $\begin{array}{l}\text { Fleshy fruits, large ( }>20 \mathrm{~mm} \text { ), indehiscent, but with soft epicarp and small seeds (up to } 10 \mathrm{~mm} \text { ); mature still attached } \\
\text { to the mother plant; attractive for arboreal mammals, bats and birds (Fig. } 1 \mathrm{G} \text { ). }\end{array}$ \\
\hline Myrmecochory (Ants) & Dry and dehiscent fruits and small seeds (up to $10 \mathrm{~mm}$ ) with an elaiosome, an appendix rich in lipids (Fig. $1 \mathrm{H})$. \\
\hline
\end{tabular}



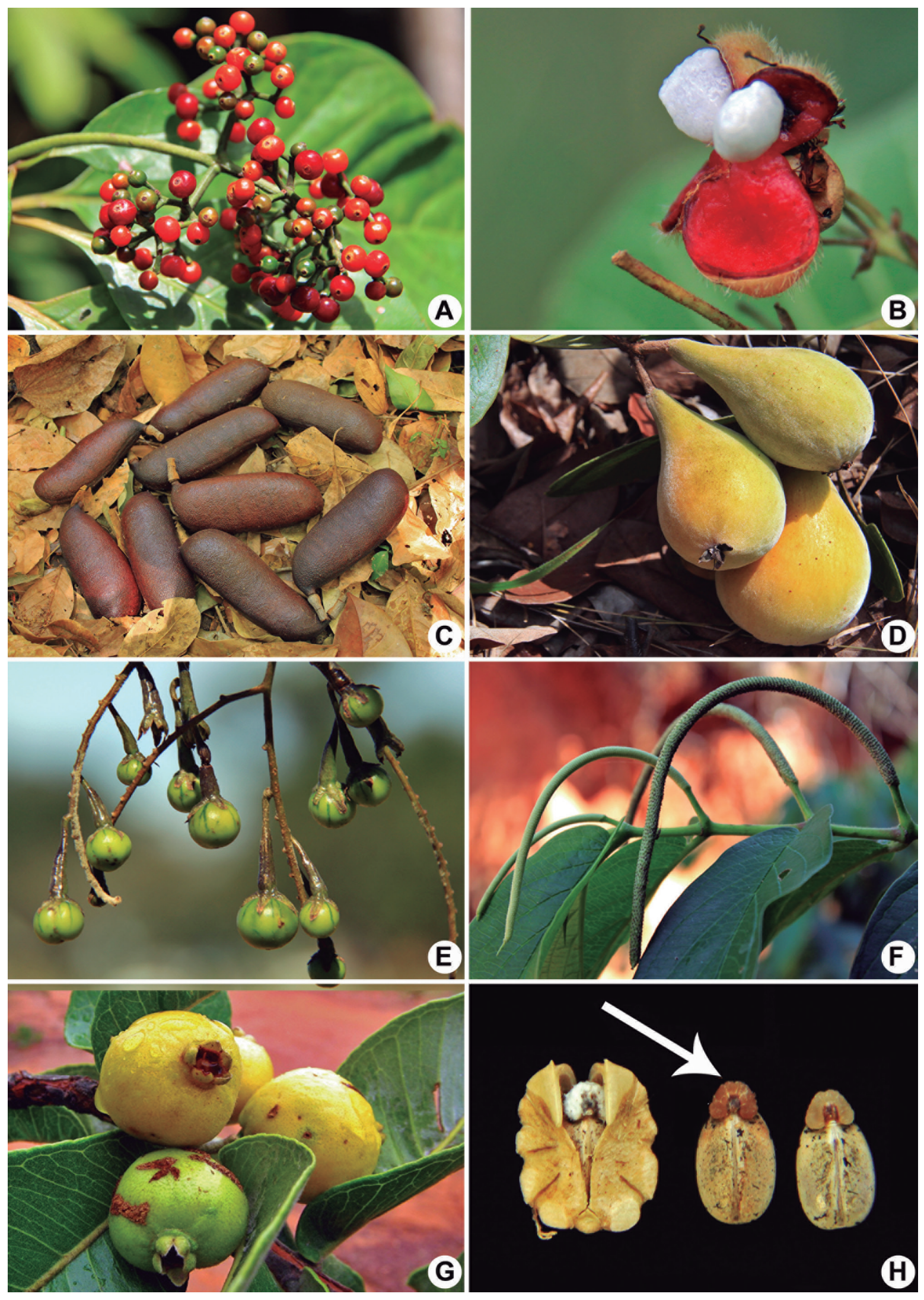

Figure 1. Examples of Cerrado fruits and syndromes. Ornithochory: (A) Psychotria carthagenensis; (B) Curatella Americana. Mastochory: (C) Hymenaea courbaril; (D) Eugenia klotzschiana. Chiropterochory: (E) Solanum paniculatum; (F) Piper aduncum. "Mixed": (G) Psidium laruotteanum. Myrmecochory: (H) Manihot violacea. (photos: Marcelo Kuhlmann). 
Likelihood analysis, assessed using bootstrapping with 1000 replications. Finally, this phylogeny was saved on "newick" format, which was played in R program to measure the phylogenetic signal of the syndromes.

\section{Results}

\section{Proportions of fruits and frugivores}

A total of 945 fruit species distributed among 285 genera and 98 families (Tab. S1 in supplementary material), and 258 species of fruit-eating vertebrates (birds, non-flying mammals and bats) distributed among 44 families (Tab. S2 in supplementary material) were found in the study area. These plant taxa represent almost $25 \%$ of the species, $65 \%$ of the genera and $91 \%$ of the families of zoochoric plants of the entire Cerrado biome (Kuhlmann \& Ribeiro 2016). Fruit-eating birds and mammals represent almost half of the bird and mammal species of the Federal District (258/600), and also almost half of the bird and mammal species of the entire biome (540/1050). As well, almost half of the fruit-eating birds and mammals of the Cerrado biome (258/540) is present in the Federal District (Tab. 2).

Ornithochory accounted for almost $60 \%$ of the species and genera of the analyzed flora, and $80 \%$ of the plant families (Fig. 2). The proportion of families related to each fruit syndrome did not differ significantly $(G=9.27, \mathrm{df}$ $=16, P=0.902)$ among the five lineages of angiosperms (basal angiosperm, monocots, basal eudicots, rosids and asterids), with exclusively ornithochorous families prevailing in all of them (45\%-68\%; Fig. 3). The proportions of life forms among zoochoric plant species were: trees (40\%),
Table 2. Comparison of the number of plant and animal species between the Federal District and the entire Cerrado biome.

\begin{tabular}{|l|c|c|}
\hline Group & $\begin{array}{c}\text { Federal } \\
\text { District }\end{array}$ & $\begin{array}{c}\text { Entire Cerrado } \\
\text { biome }\end{array}$ \\
\hline Plants (Angiosperms) & 3200 & $\sim 12000$ \\
\hline Zoochoric plants & 945 & $\sim 4000$ \\
\hline Birds and mammals & 600 & $\sim 1050$ \\
\hline Fruit-eating birds and mammals & 258 & $\sim 540$ \\
\hline
\end{tabular}

shrubs (26\%), herbs (21\%), lianas (6\%), mistletoes (4\%) and epiphytes (2\%); and the proportions of diaspore size categories were: up to $10 \mathrm{~mm}$ (78\%), 10 to $20 \mathrm{~mm}$ (10\%) and $>20 \mathrm{~mm}$ (12\%). The proportions of dispersal syndromes differed significantly among life forms $(G=475.14, \mathrm{df}=$ 20, $P<0.0001)$ and diaspore size $(G=695.83, \mathrm{df}=8, P<$ 0.0001). Ornithochory predominated among trees, shrubs, herbs, lianas and mistletoes, but not among epiphytes, for which chiropterochory predominated (Fig. 4). Mastochory was mainly distributed among trees and shrubs ( 20\%), and myrmecochory was more related to herbs and epiphytes ( $40 \%$, Fig. 4$)$. The ten families with the highest number of species and genera with fruits attractive to animals were Rubiaceae, Fabaceae, Myrtaceae, Euphorbiaceae (especially myrmecochory), Arecaceae, Lauraceae, Cucurbitaceae, Annonaceae, Melastomataceae and Moraceae.

The proportions of fruit-eating bird and mammal species in the studied area were: birds (70\%), non-flying mammals (20\%) and bats (10\%). Body size proportions were: small (74\%) and large (26\%). And proportions of methods of locomotion were: volant $(77 \%)$, terrestrial (14\%), arboreal (5\%) and arboreal/terrestrial (5\%). Of 44 frugivorous vertebrate families, $60 \%$ were birds,

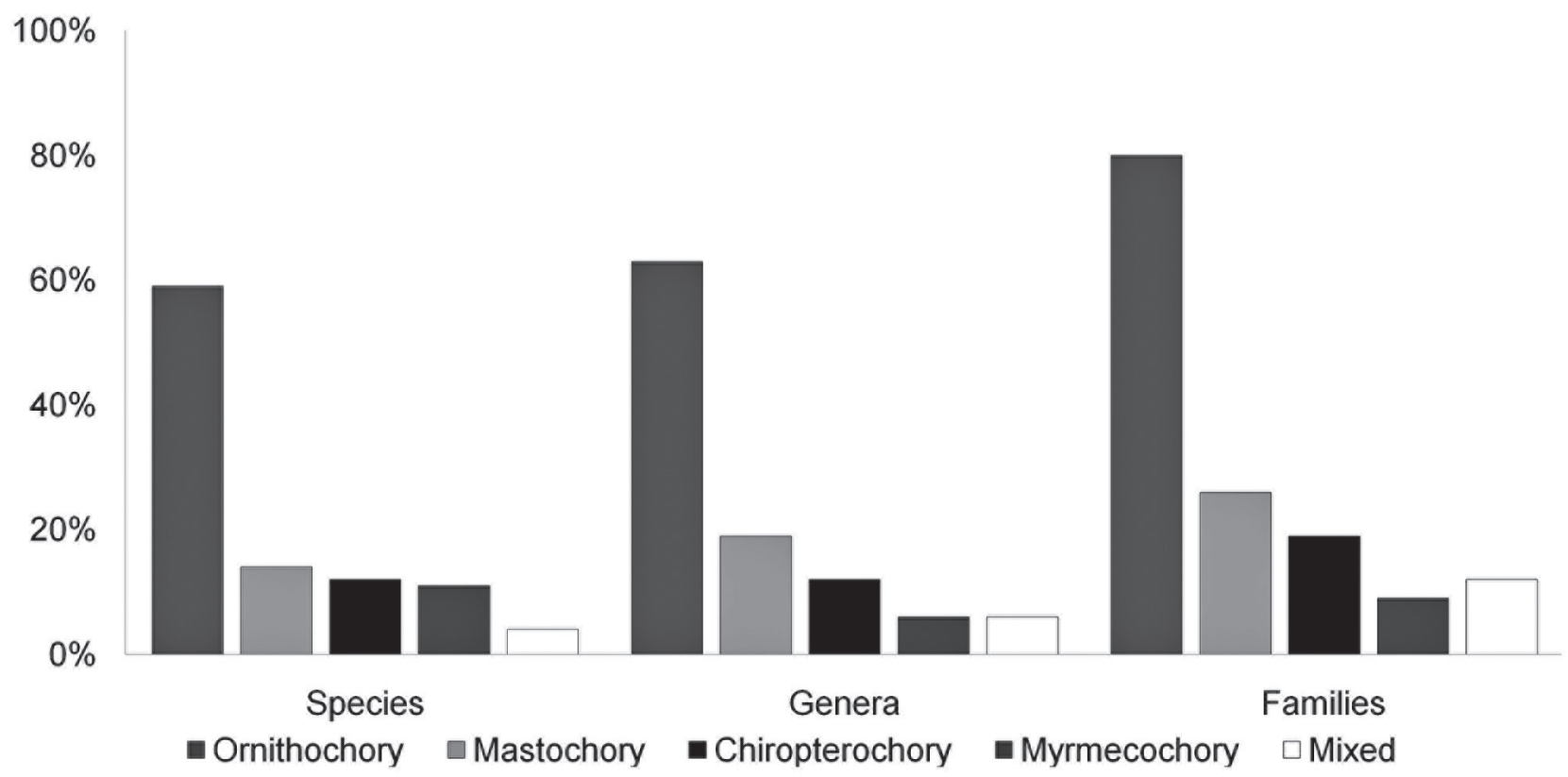

Figure 2. Proportions of plant taxa of each syndrome in a sample of 945 species, 285 genera and 98 families of the Cerrado. 


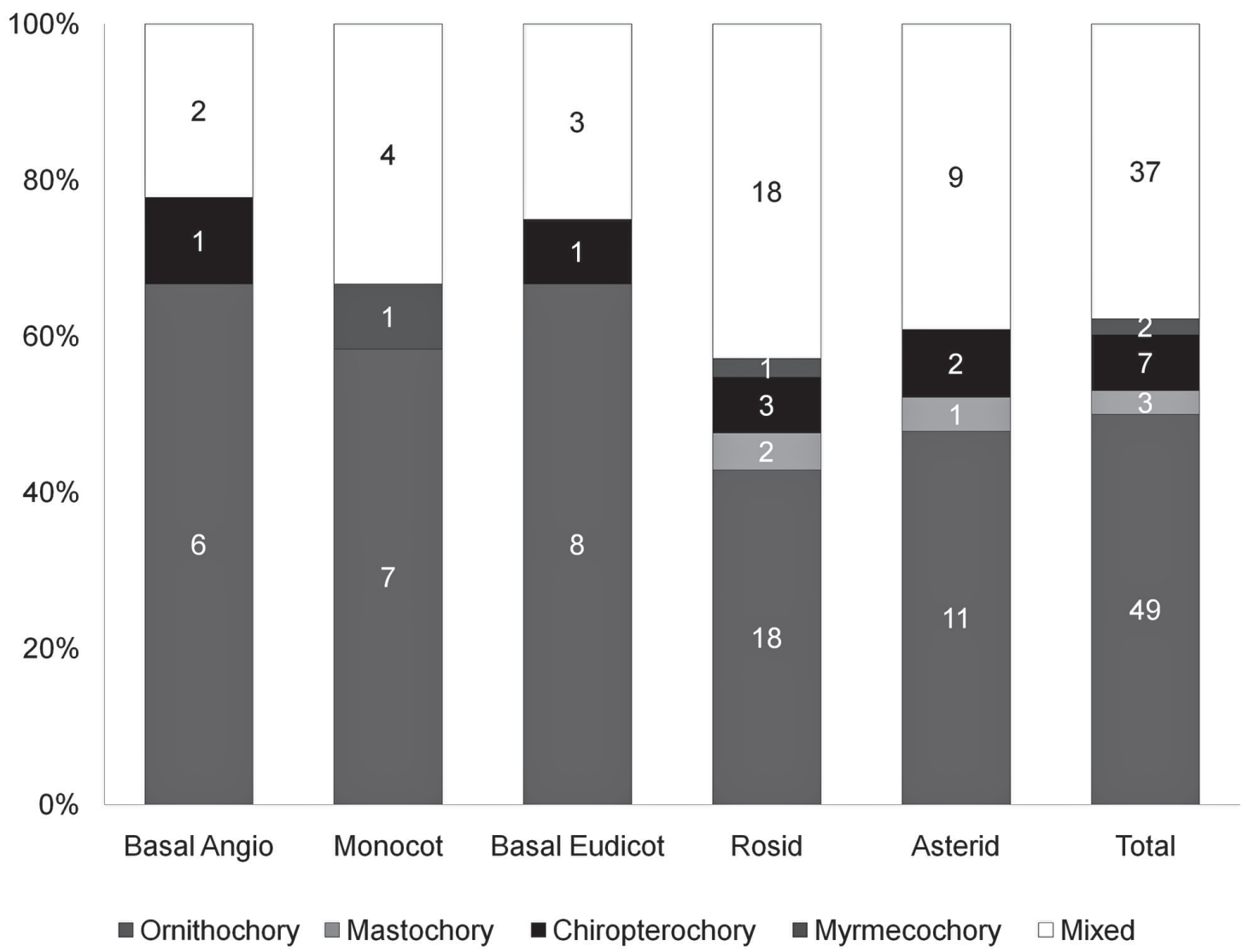

Figure 3. Proportions of Cerrado angiosperms families related to each dispersal syndrome according to major angiosperms lineages. Mixed families have more than one dispersal syndrome. Number of families is indicated.

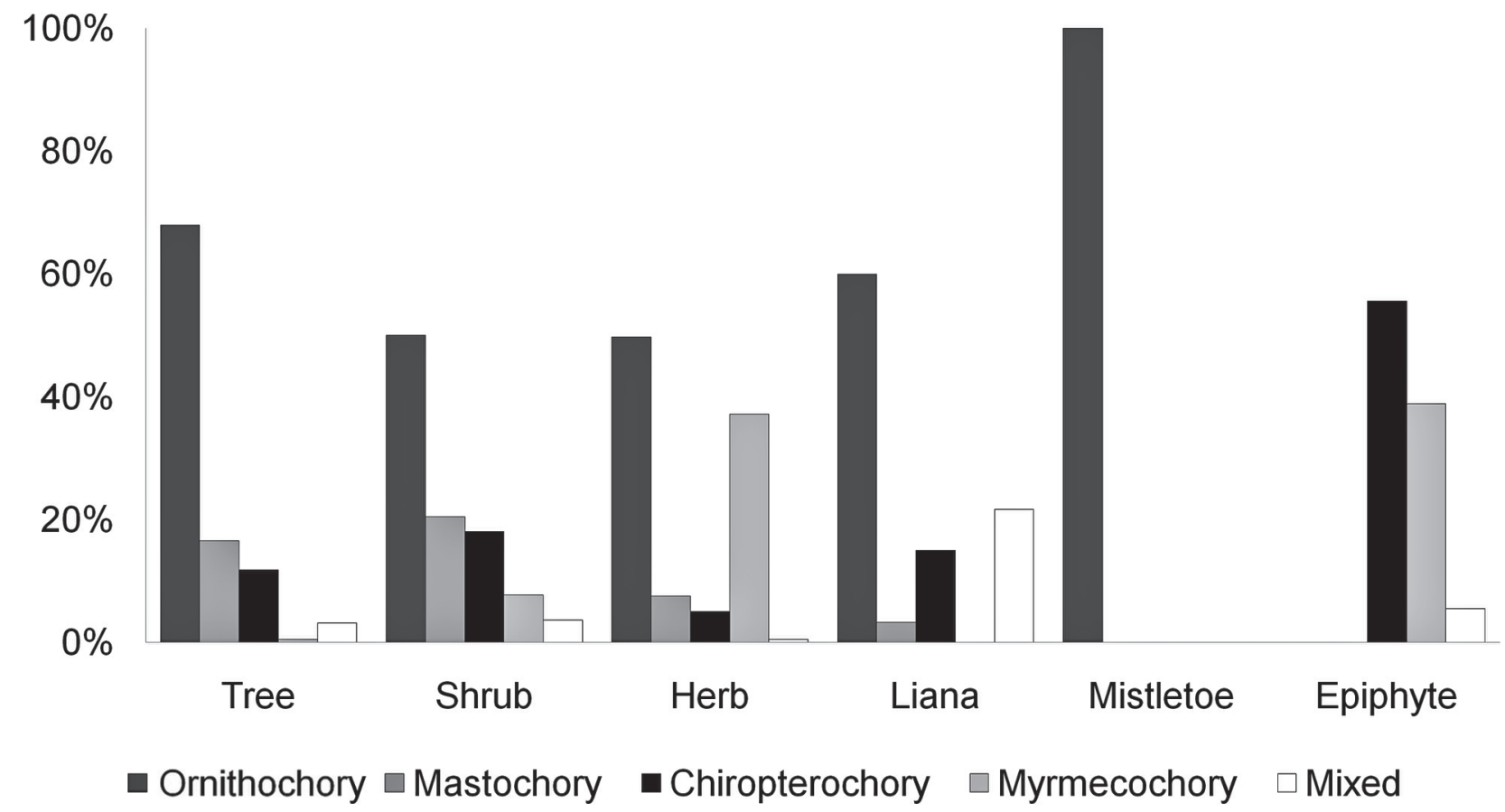

Figure 4. Proportion of species of each syndrome among vegetation life-forms in a sample of 945 spp. of Cerrado. 
followed by non-flying mammals (38\%) and one bat family (Phyllostomidae). The families with the greatest number of fruit-eating species were Thraupidae (bird), Tyrannidae (bird), Phyllostomidae (bat), Cricetidae (rodent), Psittacidae (bird), Didelphidae (marsupial), Columbidae (bird), Icteridae (bird), Picidae (bird) and Turdidae (bird). We did not analyze the proportions of species on ant families, which were beyond the scope of this study.

Among Cerrado formations, forest had the greatest number of fruit species (78\%), followed by savanna (38\%) and grassland (36\%), although many species occurred in more than one formation (47\%; Fig. 5A). The proportion of species of each dispersal syndrome varied significantly among Cerrado formations ( $G=91, \mathrm{df}=8, P<0.0001$ ). Vertebrate syndromes prevailed in forest (ornithochory-83\%, mastochory-73\%, chiropterochory-97\%, mixed-81\%), while myrmecochory prevailed in grassland (67\%). The forest was also the richest in number of species of vertebrate frugivores (82\%), followed by savanna (57\%) and grassland (44\%), with most species occurring in more than one formation $(60 \%$; Fig. 5B). The proportion of frugivorous birds, non-flying mammals and bats varied significantly among Cerrado formations $(G=21.5, \mathrm{df}=4, P=0.0002)$; all three vertebrate groups had higher proportions in forests ( $80 \%)$, and none of the bat species occurred in grassland.

\section{Phylogenetic signal in zoochorous syndromes}

We found molecular sequences data for 235 zoochorous genera and 89 families of the Cerrado in Genbank (2015). The assessment of phylogenetic signal among zoochorous syndromes resulted in low lambda $(\lambda)$ values $(\lambda=0.30$,

\section{A - Fruits (945 spp.)}

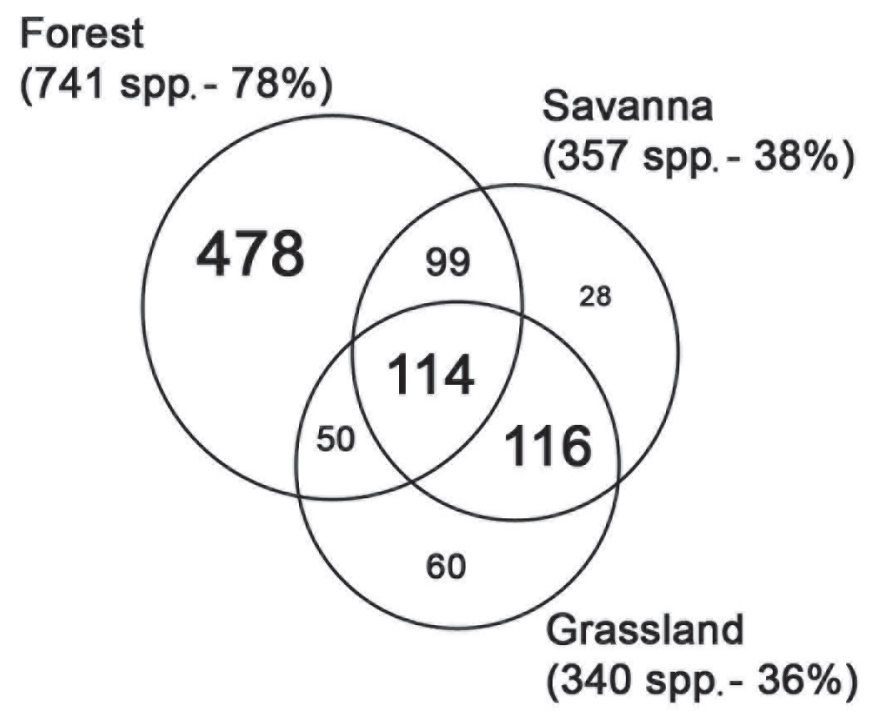

$P=0.001$ ), indicating that dispersal syndromes related to animals are not largely phylogenetically determined and seem to be liable. Mapping the syndromes on the phylogeny of Cerrado angiosperm genera confirmed the low phylogenetic signal, i.e., syndromes were mostly randomly distributed throughout the phylogenetic tree and with ornithochory dominating the phylogeny as a whole (Fig. 6).

\section{Discussion}

\section{Fruits and frugivores in Cerrado}

Here we report high diversity of fruit and frugivores of the Cerrado, which is very representative for the biome, especially at the genus and family levels. It is estimated that between 4,000 species and 400 genera of Cerrado angiosperms produce fruit that are attractive to wildlife (Kuhlmann \& Ribeiro 2016), especially birds, while about half of the vertebrate species of the biome (birds, non-flying mammals and bats) feed predominantly or partially on fruit. We found that most of the species of fruits and frugivores occurred in forest formations $(\sim 80 \%)$ and were associated mostly with woody plants (66\%), with the exception being fruits related to myrmecochory, which were associated more with grassland and herbaceous plants. However, many plant and animal species occurred in more than one formation, so these vegetation types seem to be interdependent regarding seed dispersal mutualisms. After the Cretaceous-Tertiary boundary ( $65 \mathrm{Ma}$ ) there was great diversification of fruits and fruit-eating animals, especially birds and mammals, accompanied by the development of forests (Tiffney 2004; Bolmgren \& Eriksson 2005). In this manner, the evolution

\section{B - Frugivores (258 spp.)}

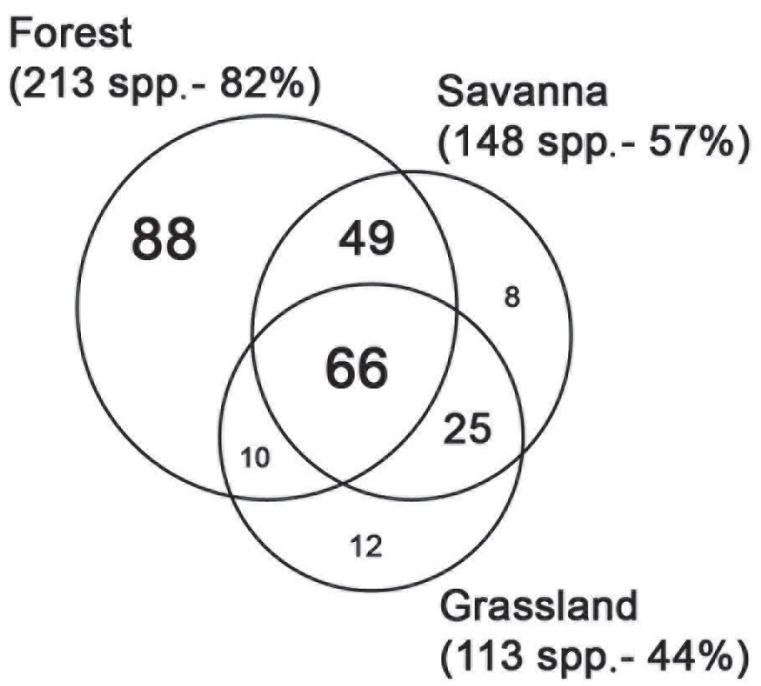

Figure 5. Number of fruit and frugivore species among the three general Cerrado formations. 


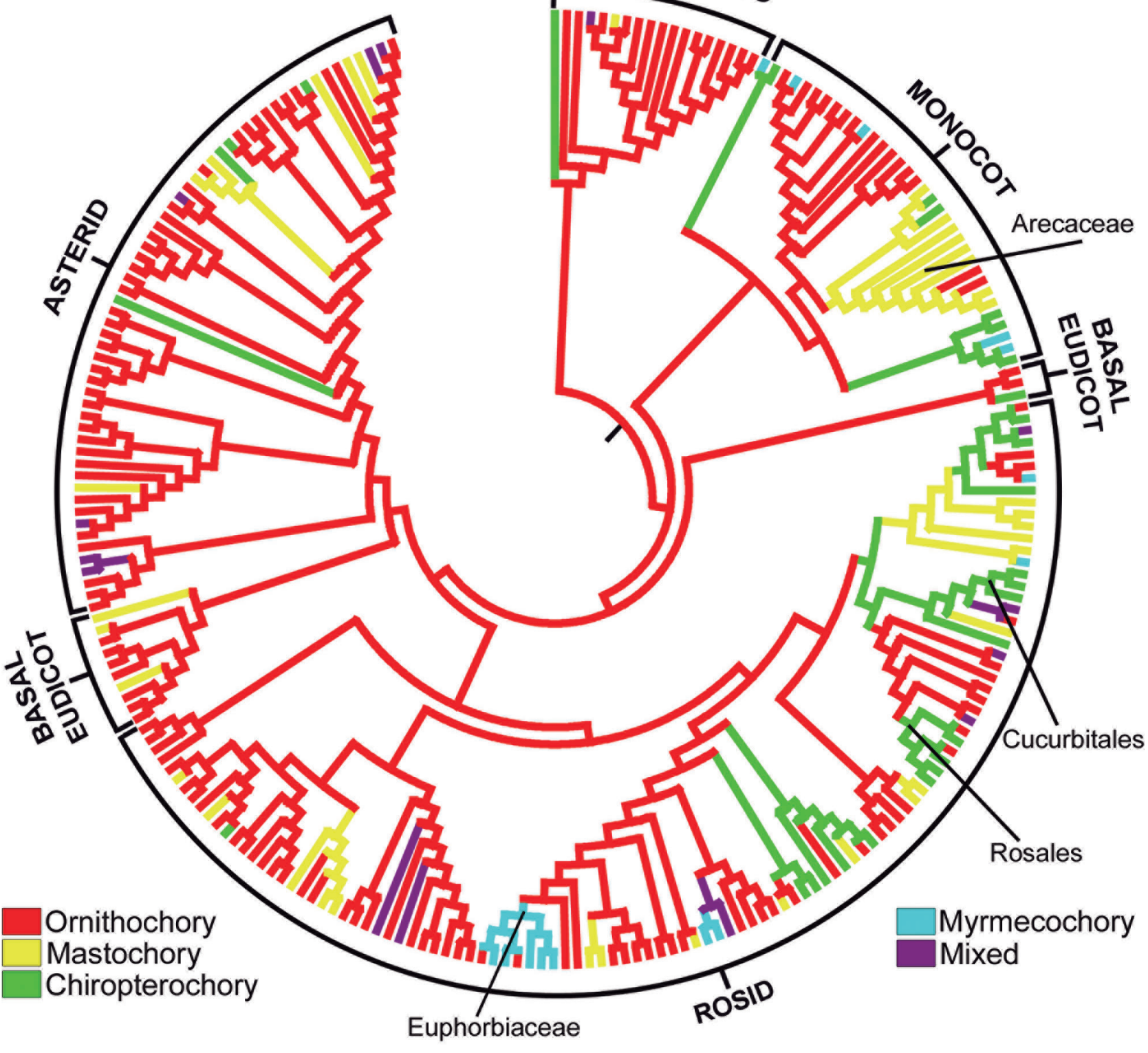

Figure 6. Phylogenetic structure and mapping of zoochorous syndromes for Cerrado angiosperms (235 genera, 89 families), grouped by major lineages: basal angiosperms, monocots, basal eudicots, rosids and asterids. Ornithochory is widely distributed throughout the phylogeny, and some phylogenetic niches related to the other syndromes are found, such as mastochory among Arecaceae (monocot), chiropterochory in Cucurbitales and Rosales (rosid) and myrmecochory in Euphorbiaceae (rosid). This phylogeny is in agreement with APG III (2009). Please see the PDF version for color reference.

of plant-frugivore interactions would have occurred by a combination of factors such as plant life forms, seed size and availability of frugivores (Eriksson 2008). Woody plants generally have larger seeds, which require vertebrates for dispersal (Eriksson et al. 2000; Moles \& Westoby 2006), and animal size plays an important role in the selection of fruits (Burns \& Lake 2009; Galetti et al. 2013). Thus, in order to conserve the unique vegetation of the Cerrado and the seed dispersal cycles of its plants, it is imperative to conserve its frugivorous fauna, especially in forest formations.
For the nearly thousand fruit species of the Cerrado included in this study (945 spp.), most (80\%) possessed diaspores (dispersal units) with diameters up to $10 \mathrm{~mm}$ and traits associated with ornithochory. Bird fruits were widely distributed throughout the phylogeny of Cerrado angiosperms, and almost half of the analyzed families exhibited traits exclusively related to ornithochory. These families included Lauraceae, Sapindaceae, Primulaceae, Phyllanthaceae, and the mistletoes families, Loranthaceae and Santalaceae, with the latter life form being $100 \%$ 
ornithochorous. For most species of tropical birds, the largest diaspores that they can swallow is about $10 \mathrm{~mm}$, and only large birds, such as toucans or cracids, are able to eat larger fruits (Wheelwright 1985; Lord 2004). Large birds are also able to eat greater number of fruits and carry seeds for longer distances, however those larger are the most vulnerable to habitat fragmentation (Galetti et al. 2013), which has impacted the Cerrado. Thus, in consequence of the low abundance of big birds in fragments, the reproductive success of plants may be dramatically affected, especially those with large fruits and seeds (Pizo 2004; Jordano et al. 2006). The evolution of a frugivorous diet in birds has been accompanied by the evolution of their biology and ecology, such as the ability to see colors (Hart \& Hunt 2007), their plumage colors (Olson \& Owens 2005) and behaviors to acquire fruits (Moermond \& Denslow 1985). Morphological differences in beaks, wings and legs also influence foraging time and the amount of fruit they can acquire and, as a result, different groups of birds, particularly at the family level, have access to different fruit types (Fleming \& Kress 2013). Some of the most significant families of fruit-eating birds of the Cerrado analyzed in this study (Thraupidae, Turdidae, Columbidae, Cotingidae, Pipridae), likely contributed prominently to the evolution of fruits in the Neotropics as a whole (Kissling et al. 2009).

Fruits related to mastochory in the analyzed Cerrado community were represented by 130 species, distributed among $20 \%$ of the zoochorous genera in the studied area. Almost $80 \%$ of these species had diaspores $>20 \mathrm{~mm}$. However, only a few of the families in this study were exclusively related to this syndrome, such as Caryocaraceae and Ebenaceae. Similar to birds, frugivorous mammals have evolved various traits related to frugivory, such as differentiated teeth, increased sensitivity to the perception of odors, and color vision in certain groups, such as primates, along with a great variety of body sizes, dietary habits and modes of locomotion (Fleming \& Kress 2013). In the Cerrado, some of the most significant mammal families that feed on fruits included Cebidae, Didelphidae, Cricetidae, Procyonidae, Tapiridae, Canidae, Dasyproctidae and Tayassuidae. The historical evolution of the Cerrado must also be considered in assessing plant-frugivore relationships because many of the animals that coevolved with these plants became extinct during the Pleistocene (10,000 years ago), including megafauna such as giant sloths (Megatherium) and mastodons (Gomphothere) (Janzen \& Martin 1982; Hansen \& Galetti 2009). Many fruits of plants currently existing in the Cerrado biome have traits that appear more related to megafauna dispersers than to extant mammals. In particular, diaspore size, seed hardness and the germination time seem to have been shaped by interactions with larger animals (Donatti et al. 2007; Guimarães et al. 2008), such as Attalea, Mauritia, Hymenaea, Dimorphandra, Caryocar, Tocoyena and Pouteria, among many others (Gottsberger \& Silberbauer-Gottsberger 2006). The loss of mega-herbivores had consequences for the Cerrado vegetation, with a greater accumulation of biomass of grasses, which facilitated for more frequent and severe fires (Galetti 2004; Gottsberger \& Silberbauer-Gottsberger 2006). The loss of megafauna also affected seed dispersal in various ways, including a reduced removal rate of large fruits, which in turn reduced the dispersal distance and geographic extent of these plant species. Furthermore, without the mega-herbivores, these plants experienced reduced genetic variability (Guimarães et al. 2008). Although extant animals, such as the tapir, the maned-wolf, the agouti, and the rhea, as well as humans and introduced animals, such as cattle and feral pigs, have contributed to the maintenance of these Cerrado fruit species over time, they contribute much less than megafauna of the past (Hansen \& Galetti 2009). Needless to say, attention needs to be paid to the conservation of the large mammals of the Cerrado, since their absence can result in increases in population size of small rodents and seed predation rates (Galetti et al. 2006; 2015), which would compromises the reproductive and regenerative cycles of native plants.

Fruits related mainly to frugivory by bats were represented by 118 species and 34 genera, most of which were from forest formations. Twenty-six species of frugivorous bats were found in the studied area. Phyllostomidae is the main family of frugivorous bats in the Neotropics (160 species; Simmons 2005), and is represented predominantly by the subfamilies Carolliinae and Stenodermatinae (Lobova et al. 2009; Bredt et al. 2012). Chiropterochory was not randomly distributed among Cerrado angiosperms in the present study, with some families being well represented, such as Solanaceae, Piperaceae, Moraceae, Araceae, Chrysobalanaceae, Hypericaceae, Icacinaceae and Cucurbitaceae. Chiropterochory was also important for epiphytes, such as the families Araceae and Bromeliaceae. Bats are considered important in the early stages of forest regeneration, and are not typically found in the herbaceous layer (Muscarella \& Fleming 2007). Indeed, many of the bat fruits analyzed were shrubs or small primary trees, such as Piper, Cecropia, Vismia and Solanum. However, some generalist frugivorous bats, such as Artibeus, can feed on a wide range of fruits of different sizes, and in different vegetation strata, depending on food availability (Aguiar \& Marinho-Filho 2004; 2007). In a single night, frugivorous bats can travel long distances in search for food. This and other features of fruit-eating bats such as the quick passage of seeds through its digestive tract and the in-flight defecation, suggest that these animals are efficient seed dispersers (Fleming \& Heithaus 1981; Fleming \& Kress 2013). In view of this, experiments have been developed to improve the services bats provide to the recovery of degraded areas (Mikich \& Bianconi 2005; Reis et al. 2010; Campos et al. 2012). For example, the use of essential oils and artificial perches to attract these animals can also be applied to restoration of a variety of different forest and 
savanna formations of the Cerrado.

Typically myrmecochorous-dispersed plants comprised 102 species in the studied area, distributed among 6\% of the zoochorous genera analyzed. This syndrome was characterized by having capsular fruits and seeds with an elaiosome, an appendix rich in lipids (Thompson 1981). Unlike the other syndromes, myrmecochory predominated in more open formations such as grasslands and among herbs. Herbaceous plants generally have less energy to invest in the production of fleshy fruits than do woody plants and, in general, have lower distances of dispersal from the mother plant, and so are favored by myrmecochory (Hughes et al. 1993; Giladi 2006). Some plant families were more dependent on seed dispersal by ants in the studied area, such as Marantaceae, Turneraceae, Euphorbiaceae, Poaceae and Polygalaceae. Ants of Attini and Ponerinae can also promote secondary seed dispersal of a variety of plants in the Cerrado, such as Hymenaea, Copaifera, Virola, Myrcia and Miconia (Leal \& Oliveira 2000), by facilitating germination through cleaning the pulp from seeds and carry them to favorable sites (Beattie 1985; Pizo \& Oliveira 2000; Christianini \& Oliveira 2010). Different ant guilds, such as carnivorous or fungivorous, also have preferences for different types of fruit based on the chemical content of the pulp (Pizo \& Oliveira 2000). In this way, ants could have influenced the evolution of a diversity of fruit traits, both myrmecochorous and non-myrmecochorous, and it appears that these small animals have great influences on the ecosystems they inhabit (Christianini et al. 2012).

Fruits related to the "mixed" syndrome of dispersal, in which we include fruits with soft epicarps and small seeds immersed in pulp, comprised only 36 species in the studied area. Fruits with these traits included genera such as Annona, Cereus, Mouriri, Psidium, Passiflora, Rubus, Alibertia, Cordiera and Genipa, which are suitable for birds, bats and primates or other arboreal mammals (personal observations). However, $37 \%$ of the families analyzed exhibited more than one syndrome, which we classified as "mixed families". These taxa could provide insights into the phylogenetic relationships involving fruits and their syndromes, which we discuss further below. It is important to remember that these dispersal syndromes only reflect traits that are most likely to interact with particular animals, and that different frugivores can consume different fruits (Fleming \& Kress 2013; Howe 2016). Furthermore, many vertebrates that eat fruits do not necessarily disperse seeds to sites favorable for germination and recruitment (Schupp et al. 2010), or may be seed predators (like many Psittacidae and Cricetidae). For the conservation of many tropical biomes, including Cerrado, the reliability of the mutualistic nature of dispersal syndromes still needs to be evaluated, which can be done using network approaches (Bascompte \& Jordano 2014). It is implicit in dispersal syndromes that fruit traits have evolved from differential selection by dispersal agents, but the set of frugivores that can interact with fruits, and their effectiveness at dispersing seeds, can vary over time and among different regions, so the syndromes approach needs to be employed with care (Fleming \& Kress 2013; Howe 2016).

Finally, we briefly address the importance of lizards as frugivores and seed dispersers. In fact, some lizard families have species that consume fleshy fruit in some quantity, especially in islands (Valido \& Olesen 2007). Fruits are important food resources for animals like tortoises and herbivorous or omnivorous lizards (Valido et al. 2003), and some case studies of frugivory have been reported involving reptiles that occur in the Cerrado, such as Tupinambis (Teiidae) (Castro \& Galetti 2004), Chelonoidis (Testudinidae) (Jerozolimski et al. 2009), and Anolis (Polychrotidae) (Herrel et al. 2004). Nonetheless, it is still difficult to define a lizardfruit syndrome, since these animals seem to interact with a wide range of fruits with different traits, and which can vary among different floras globally (Valido \& Olesen 2007).

\section{Phylogenetic signal in zoochorous syndromes}

The evolution of fruits in tropical regions such as the Cerrado involves a great diversity of plants and animals, which differ greatly in size, morphology and feeding habits (Fleming \& Kress 2013). Analyses of the zoochorous syndromes in this study (ornithochory, mastochory, chiropterochory, myrmecochory and "mixed") found that they had low phylogenetic signal at the genus level, indicating that genetically closely related zoochorous fruits are likely to be very different morphologically. This contrasts with the recent findings of Kuhlmann \& Ribeiro (2016), which showed that the main syndromes (zoochory, anemochory and autochory) had high phylogenetic signal in the Cerrado. It appears that the evolution of exclusively animal seed dispersal in tropical environments is phylogenetically flexible, such that plant-frugivore interactions can be very generalized, yet responding to a set of selective pressures of the environment, such as availability of dispersal agents (different groups of frugivores) and changes in vegetation structure (Fleming \& Kress 2013). The mapping of zoochorous syndromes on the Cerrado angiosperm phylogeny revealed that only a few closely related taxa retained the same syndrome, for example, mastochory among Arecaceae (Monocot), chiropterochory in Cucurbitales and Rosales (Rosid) and myrmecochory in Euphorbiaceae (Rosid). Ornithochory was widely distributed throughout the phylogeny, and many families had more than one kind of syndrome, which could further reflects the low phylogenetic signal.

\section{Implications for conservation and final considerations}

Plant-frugivore interactions in tropical regions can be quite complex, with a great number of plant species 
depending on animals for seed dispersal, and also many animals depending on fruit resources for survival (Jordano et al. 2006). In this way, in order to retain biodiversity in highly diverse biomes such as Cerrado, conservation or restoration using the ecological services of fruit-eating animals must consider multiple and complementary sources of fruits (Howe 2016). Different plant species produce fruits at different times of the year and fruiting phenologies can also vary greatly from year to year (Batalha \& Martins 2004). In the Cerrado, zoochoric fruits reach their fruiting peak during spring and summer, on the wet season, but on dry season there are also many species that provide important food resource for fauna, such as Hymenaea spp., Copaifera ssp., Schinus terebinthifolius and others (M. Kuhlmann unpubl. res.). Furthermore, generalist and high productive plants, such as Cecropia, Ficus, Solanum, Euterpe, are great candidates for keystone species because many fruitingeating vertebrates eat them and also their long fruiting seasons provide resources when fruits of other species are scarce (Diaz-Martin et al. 2014). In this sense, to support large assemblages of frugivores and the services they provide in tropical regions, it is important to conserve or restore heterogeneous seed-dispersal interactions, thereby creating physical environments that accelerate ecological succession (Jordano et al. 2006; Howe 2016). For this, we first need to know the fruit-eating animals and the plants they interact within a given community, as addressed in this study.

Here, we have provided an overview of the relationships between fruits and frugivores of the Cerrado, as a starting point for understand the ecology and evolution of seed dispersal by animals in this biome. It was shown that ornithochory predominated among Cerrado angiosperm taxa (both in lower and higher taxonomic levels) and that almost half of the birds and mammals, both in the Federal District and in the entire biome, seem to consume fruits, at least as a diet complement, and especially birds. Most fruits and frugivores inhabit forests, but many also occur in more than one Cerrado vegetative formation, such as savannas and grasslands. Therefore, it seems that forest formations are fundamental for the functional stability of plantfrugivore mutualisms in all three vegetative formations of the biome, and vice-versa. The higher proportion of ornithochorous fruits and the distribution of fruits with different traits within families may have contributed to the low phylogenetic signal found for the zoochorous syndromes, which suggests that plant-frugivore interactions may be more evolutionarily labile in Neotropic regions, such as the Cerrado. We anticipate that the patterns of the relationships between fruits and frugivores illuminated in this study for the formations of the Cerrado will help to elucidate the ecology and evolution of plant-animal interactions in general. We also hope our findings will contribute to a better appreciation of how fundamentally important seed dispersal processes involving animals are to the conservation and restoration of this mega-diverse biome.

\section{Acknowledgments}

We thank the University of Brasilia Botany Pos Graduation Program and Embrapa Cerrados for logistical support; CAPES for the scholarship of the first author; Cassia Munhoz, Carolyn Proença, Bruno Walter, Marcelo Simon, Adriano Darosci, Ludmilla Aguiar and Mauro Galetti for comments on earlier drafts of the manuscript; and Erik Wild for reviewing the language of this manuscript.

\section{References}

Aguiar LMDS, Machado RB, Marinho-Filho J. 2004. A diversidade biológica do Cerrado. Ecologia e Caracterização do Cerrado 1: 19-42.

Aguiar LMDS, Marinho-Filho J. 2004. Activity patterns of nine phyllostomid bat species in a fragment of the Atlantic Forest in southeastern Brazil. Revista Brasileira de Zoologia 21: 385-390.

Aguiar LMDS, Marinho-Filho J. 2007. Bat frugivory in a remnant of Southeastern brazilian Atlantic forest. Acta Chiropterologica 9: 251260.

APG - Angiosperm Phylogeny Group III. 2009. An update of the Angiosperm Phylogeny Group classification for the orders and families of flowering plants: APG III. Botanical Journal of the Linnean Society 161: 105-121.

Bagno MA, Marinho-Filho J. 2001. A avifauna do Distrito Federal: uso de ambientes abertos e florestais e ameaças. In: Ribeiro JF, Fonseca CEL, SousaSilva JC. (eds.) Cerrado - Caracterização e Recuperação de Matas de Galeria. Planaltina, Embrapa Cerrados. p. 495528.

Barroso GM, Morim MP, Peixoto AL, Ichaso CLF. 1999. Frutos e sementes - morfologia aplicada à sistemática de dicotiledôneas. Viçosa, Editora UFV.

Bascompte J, Jordano P. 2014. Mutualistic networks. Princeton, Princeton Univ. Press.

Batalha MA, Martins FR. 2004. Reproductive phenology of the cerrado plant community in Emas National Park (central Brazil). Australian Journal of Botany 52: 149-161.

Beattie AJ. 1985. The evolutionary ecology of ant-plant mutualisms. Cambridge, Cambridge University Press.

Bello C, Galetti M, Pizo MA, et al. 2015. Defaunation affects carbon storage in tropical forests. Science Advances 1(11): e1501105. DOI: 10.1126/sciadv.1501105.

Blomberg SP, Garland JRT, Ives AR. 2003. Testing for phylogenetic signal in comparative data: behavioral traits are more labile. Evolution 57: 717-745.

Bolmgren K, Eriksson O. 2005. Fleshy fruits-origins, niche shifts, and diversification. Oikos 109: 255-272.

Bolmgren K, Eriksson O. 2010. Seed mass and the evolution of fleshy fruits in angiosperms. Oikos 119: 707-718.

Bredt A, Uieda W, Pedro WA. 2012. Plantas e morcegos na recuperação de áreas degradadas e na paisagem urbana. Brasília, Rede de Sementes do Cerrado.

Bugoni L, Mohr LV, Scherer A, Efe MA, Scherer SB. 2013. Biometry, molt and brood patch parameters of birds in southern Brazil. Brazilian Journal of Ornithology 10: 10.

Burns KC, Lake B. 2009. Fruit-frugivore interactions in two southern hemisphere forests: allometry, phylogeny and body size. Oikos 118: 1901-1907.

Campos WH, Neto AM, Peixoto HJC, Godinho LB, Silva E. 2012. Contribuição da fauna silvestre em projetos de restauração ecológica no Brasil. Pesquisa Florestal Brasileira 32: 429.

Castro ERD, Galetti M. 2004. Frugivoria e dispersão de sementes pelo lagarto teiú Tupinambis merianae (Reptilia: Teiidae). Papéis Avulsos de Zoologia (São Paulo), 44: 91-97.

Cavalcanti TB, Ramos AE. 2001. Flora do Distrito Federal, Brasil. Vol. I. Brasília, Embrapa Recursos Genéticos e Biotecnologia. 


\section{Marcelo Kuhlmann and José Felipe Ribeiro}

Cavender-Bares J, Kozak KH, Fine PV, Kembel SW. 2009. The merging of community ecology and phylogenetic biology. Ecology Letters 12: 693-715.Christianini AV, Mayhé-Nunes AJ, Oliveira PS. 2012. Exploitation of fallen diaspores by ants: are there ant-plant partner choices? Biotropica 44: 360-367.

Christianini AV, Oliveira PS. 2010. Birds and ants provide complementary seed dispersal in a neotropical savanna. Journal of Ecology 98: 573582.

Costa MH, Pires GF. 2010. Effects of Amazon and Central Brazil deforestation scenarios on the duration of the dry season in the arc of deforestation. International Journal of Climatology 30: 1970-1979.

CTFB. 2016. Catálogo Taxonômico da Fauna do Brasil. <http://fauna.jbrj. gov.br/fauna/listaBrasil/PrincipalUC/PrincipalUC.do?lingua=pt $>$. 23 August 2016.

Diaz-Martin Z, Swamy V, Terborgh J, Alvarez-Loayza P, Cornejo F. 2014. Identifying keystone plant resources in an Amazonian forest using a long-term fruit-fall record. Journal of Tropical Ecology 30: 291-301.

Diniz IR, Filho JM, Machado RB, Cavalcanti RB. 2010. Cerrado: Conhecimento Científico quantitativo como subsídio para ações de conservação. Brasília, Editora Thesaurus.

Donatti CI, Galetti M, Pizo MA, Guimaraes PR, Jordano P. 2007. Living in the land of ghosts: fruit traits and the importance of large mammals as seed dispersers in the Pantanal, Brazil. In: Dennis AJ, Green RJ, Schupp EW, Westcott DA. (eds.) Seed dispersal: theory and its application in a changing world. Wallingford, Commonwealth Agricultural Bureau International. p. 104-123.

Eriksson O. 2008. Evolution of seed size and biotic seed dispersal in angiosperms: paleoecological and neoecological evidence. International Journal of Plant Sciences 169: 863-870.

Eriksson O, Friis EM, Lofgren P. 2000. Seed size, fruit size, and dispersal systems in angiosperms from the early cretaceous to the late Tertiary. American Naturalist 156: 47-58.

Fauna-DF. 2016. Lista da fauna do Distrito Federal. Instituto Brasília Ambiental. <http://www.ibram.df.gov.br/component/content/ article/273.html>. 30 May 2016.

Fleming TH, Breitwisch R, Whitesides G. 1987. Patterns of tropical vertebrate frugivore diversity. Annual Review of Ecology and Systematics 18: 91-109.

Fleming TH, Heithaus ER. 1981. Frugivorous bats, seed shadows, and the structure of tropical forests. Biotropica 13: 45-53.

Fleming TH, Kress WJ. 2013. The ornaments of life: coevolution and conservation in the tropics. Chicago, University of Chicago Press.

Forzza RC, Leitman PM, Costa AF, et al. 2016. Lista de Espécies da Flora do Brasil. Jardim Botânico do Rio de Janeiro. <http://floradobrasil. jbrj.gov.br/>. 30 May 2016.

Galetti M. 2004. Parks of the Pleistocene: recreating the Cerrado and the Pantanal with megafauna. Natureza e Conservação 2: 93-100.

Galetti M, Donatti CI, Pires AS, Guimarães PR, Jordano P. 2006. Seed survival and dispersal of an endemic Atlantic forest palm: the combined effects of defaunation and forest fragmentation. Botanical Journal of the Linnean Society 151: 141-149.

Galetti M, Guevara R, Côrtes MC, et al. 2013. Functional extinction of birds drives rapid evolutionary changes in seed size. Science 340: 1086-1090.

Galetti M, Guevara R, Neves CL, et al. 2015. Defaunation affect population and diet of rodents in Neotropical rainforests. Biological Conservation 190: 2-7.

GenBank. 2015. NIH genetic sequence database. <http://www.ncbi.nlm. nih.gov/genbank>. 30 Mar. 2015.

Giladi I. 2006. Choosing benefits or partners: a review of the evidence for the evolution of myrmecochory. Oikos 112: 481-492.

Gottsberger G, Silberbauer-Gottsberger I. 2006. Life in the Cerrado: a South American tropical seasonal vegetation. Vol. II. Pollination and seed dispersal. Ulm, Reta Verlag.

Guimarães PR, Galetti M, Jordano P. 2008. Seed dispersal anachronisms: rethinking the fruits extinct megafauna ate. PLoS One 3: e1745. DOI: 10.1371/journal.pone.0001745.

Gwynne JA, Ridgely RS, Tudor G, Argel M. 2010. Aves do Brasil: Pantanal \& Cerrado. São Paulo, Ed. Horizonte, Wildlife Conservation Society.
Hansen DM, Galetti M. 2009. The forgotten megafauna. Science 324: 42-43. Hart NS, Hunt DM. 2007. Avian visual pigments: characteristics, spectral tuning, and evolution. American Naturalist 169: S7-S26.

Herrel A, Vanhooydonck B, Joachim R, Irschick DJ. 2004. Frugivory in polychrotid lizards: effects of body size. Oecologia 140: 160-168.

Herrera CM. 1985. Determinants of plant-animal coevolution: the case of mutualistic dispersal of seeds by vertebrates. Oikos 132-141.

Howe HF. 2016. Making dispersal syndromes and networks useful in tropical conservation and restoration. Global Ecology and Conservation 6: 152-178.

Howe HF, Schupp EW, Westley LC. 1985. Early consequences of seed dispersal for a neotropical tree (Virola surinamensis). Ecology 66: 781-791.

Howe HF, Smallwood J. 1982. Ecology of seeds dispersal. Annual Review of Ecology and Systematics 13: 201-228.

Howe HF, Westley LC. 2009. Ecology of pollination and seed dispersal. Plant Ecology 2: 262-283.

Hughes L, Westoby M, Johnson AD. 1993. Nutrient costs of vertebrateand ant-dispersed fruits. Functional Ecology 7: 54-62.

Janzen DH. 1969. Seed-eaters versus seed size, number, toxicity and dispersal. Evolution 23: 1-27.

Janzen DH. 1974. The de-flowering of Central America. Natural History 83: 49.

Janzen DH, Martin PS. 1982. Neotropical anachronisms: the fruits the gomphotheres ate. Science 215: 19-27.

Jerozolimski A, Ribeiro MBN, Martins M. 2009. Are tortoises important seed dispersers in Amazonian forests? Oecologia 161: 517-528.

Jordano P. 2000. Fruits and frugivory. In: Fenner M. (ed.) Seeds: the ecology of regeneration in plant communities. 2nd. edn. Wallingford, CABI Publ. p. 125-166.

Jordano P, Forget PM, Lambert JE, Böhning-Gaese K, Traveset A, Wright SJ. 2011. Frugivores and seed dispersal: mechanisms and consequences for biodiversity of a key ecological interaction. Biology Letters 7: 321-323.

Jordano P, Galetti M, Pizo MA, Silva WR. 2006. Ligando frugivoria e dispersão de sementes à biologia da conservação. In: Duarte $\mathrm{CF}$, Bergallo HG, Santos MA, Va AE. (eds.) Biologia da conservação: essências. São Paulo, Editorial Rima. p. 411-436.

Jordano P, Herrera CM. 1995. Shuffling the offspring: uncoupling and spatial discordance of multiple stages in vertebrate seed dispersal. Ecoscience 2: 230-237.

Kissling WD, Böhning-Gaese K, Jetz W. 2009. The global distribution of frugivory in birds. Global Ecology and Biogeography 18: 150-162.

Klink CA, Machado RB. 2005. Conservation of the Brazilian Cerrado. Conservation Biology 19: 707-713.

Kuhlmann M, Fagg CW. 2012. Frutos e sementes do Cerrado atrativos para fauna: guia de campo. Brasília, Rede de Sementes do Cerrado.

Kuhlmann M, Ribeiro JF. 2016. Evolution of seed dispersal in the Cerrado biome: ecological and phylogenetic considerations. Acta Botanica Brasilica 30: 271-282.

Leal IR, Oliveira PS. 2000. Foraging ecology of attine ants in a Neotropical savanna: seasonal use of fungal substrate in the cerrado vegetation of Brazil. Insectes Sociaux 47: 376-382.

Lobova TA, Geiselman CK, Mori SA. 2009. Seed dispersal by bats in the Neotropics. New York, Botanical Garden.

Lord JM. 2004. Frugivore gape size and the evolution of fruit size and shape in southern hemisphere floras. Austral Ecology 29: 430-436.

Lorenzi H. 2009. Árvores brasileiras: manual de identificação e cultivo de plantas arbóreas nativas do Brasil. Nova Odessa, Editora Plantarum.

Losos JB. 2008. Phylogenetic niche conservatism, phylogenetic signal and the relationship between phylogenetic relatedness and ecological similarity among species. Ecology Letters 11: 995-1003.

Marinho-Filho J, Rodrigues FHG, Juarez KM. 2002. The Cerrado mammals: diversity, ecology and natural history. In: Oliveira OS, Marquis RJ (eds.). The Cerrado of Brazil. Nova York, Editora Columbia University. p. 267-284.

Marini MA, Motta-Junior JC, Vasconcellos LA, Cavalcanti RB. 1997. Avian body masses from the cerrado region of central Brazil. Ornitologia Neotropical 8: 93-99. 
Markl JS, Schleuning MP, Forget M, et al. 2012. Meta-analysis of the effects of human disturbance on seed dispersal by animals. Conservation Biology 26: 1072-1081.

McDonald JH. 2014. Handbook of Biological Statistics. 3rd. edn. Baltimore, Sparky House Publishing.

Mendonça RC, Felfili JM, Walter BMT, et al. 2008. Flora vascular do bioma Cerrado: checklist com 12.356 espécies. In: Sano SM, Almeida SP, Ribeiro JF. (eds.) Cerrado: Ecologia e Flora. Vol. 2. Brasília, Embrapa Cerrados/ Embrapa Informação Tecnológica. p. 422-439.

Mikich SB, Bianconi GV. 2005. Potencializando o papel dos morcegos frugívoros na recuperação de áreas degradadas. Pesquisa Florestal Brasileira 51: 155.

MMA - Ministério do Meio Ambiente. 2015. Mapeamento do uso e cobertura do Cerrado: projeto TerraClass Cerrado 2013/mma/sbf. Brasília, MMA.

Moermond TC, Denslow JS. 1985. Neotropical avian frugivores: patterns of behavior, morphology, and nutrition, with consequences for fruit selection. Ornithological Monographs 36: 865-897.

Moles AT, Westoby M. 2006. Seed size and plant strategy across the whole life cycle. Oikos 113: 91-105.

Mouquet N, Devictor V, Meynard CN, et al. 2012. Ecophylogenetics: advances and perspectives. Biological Reviews 87: 769-785.

Münkemüller T, Lavergne S, Bzeznik B, et al. 2012. How to measure and test phylogenetic signal. Methods in Ecology and Evolution 3: 743-756.

Muscarella R, Fleming TH. 2007. The role of frugivorous bats in tropical forest succession. Biological Reviews of the Cambridge Philosophical Society 82: 573-590.

Olson VA, Owens IPF. 2005. Interspecific variation in the use of carotenoidbased coloration in birds: diet, life history and phylogeny. Journal of Evolutionary Biology 18: 1534-1546.

Pagel M. 1999. Inferring the historical patterns of biological evolution. Nature 401: 877-884.

Pijl L. 1982. Principles of Dispersal in Higher Plants. Berlin, Heidelberg, New York, Springer-Verlag.

Pinheiro F, Ribeiro JF. 2001. Síndromes de dispersão de sementes em Matas de Galeria do Distrito Federal. In: Ribeiro JF, Fonseca CEL, Sousa-Silva JC. (eds.) Cerrado: caracterização e recuperação de Matas de Galeria. Planaltina, Embrapa Cerrados. p. 335-378.

Pizo MA. 2004. Frugivory and habitat use by fruit-eating birds in a fragmented landscape in southeast Brazil. Ornitologia Neotropical 15(supl.): 117-126.

Pizo MA, Oliveira PS. 2000. The Use of Fruits and Seeds by Ants in the Atlantic Forest of Southeast Brazil. Biotropica 32: 851-861.

PLANAVEG. 2014. Plano Nacional de Recuperação da Vegetação Nativa. <http://www.mma.gov.br/images/arquivo/80049/Planaveg/ PLANAVEG_20-11-14.pdf $>30$ May 2016.

Proença CEB, Munhoz CBR, Jorge CL, Nóbrega MGG. 2001. Listagem e nível de proteção das espécies de fanerógamas do Distrito Federal, Brasil. In: Cavalcanti TB, Ramos AE. (eds.) Flora do Distrito Federal I. Brasília, Embrapa Recursos Genéticos e Biotecnologia. p.89-359.

Ratter JA, Ribeiro JF, Bridgewater S. 1997. The Brazilian cerrado vegetation and threats to its biodiversity. Annals of Botany 80: 223-230.

Reis A, Bechara FC, Tres DR. 2010. Nucleation in tropical ecological restoration. Scientia Agricola 67: 244-250.

Reis NR, Fregonezi MN, Peracchi AL, Shibatta OA. 2013. Morcegos do Brasil: Guia de campo. Rio de Janeiro, Technical Books Editora.

Reis NR, Peracchi AL, Pedro WA, Lima IP. 2006. Mamíferos do Brasil. Londrina, Universidade Estadual de Londrina.
Revell LJ, Harmon LJ, Collar DC. 2008. Phylogenetic signal, evolutionary process, and rate. Systematic Biology 57: 591-601.

Revell LJ. 2012. Phytools: an R package for phylogenetic comparative biology (and other things). Methods in Ecology and Evolution 3: 217-223.

Rezende EL, Jordano P, Bascompte J. 2007. Effects of phenotypic complementarity and phylogeny on the nested structure of mutualistic networks. Oikos 116: 1919-1929.

Ribeiro JF, Walter BMT. 2008. As principais fitofisionomias do bioma Cerrado. In: Sano SM, Almeida SP, Ribeiro JF. (eds.) Cerrado: Ecologia e Flora. Vol. 1. Brasília, Embrapa Cerrados/Embrapa Informação Tecnológica. p. 151-212.

Sano EE, Rosa R, Brito JL, Ferreira LG. 2008. Mapeamento semidetalhado do uso da terra do Bioma Cerrado. Pesquisa Agropecuaria Brasileira 43: 153-156.

Schupp EW, Jordano P, Gomez JM, 2010. Seed dispersal effectiveness revisited: A conceptual review. New Phytologist 188: 333-353.

Sebastián-González E, Dalsgaard B, Sandel B, Guimarães PR. 2015. Macroecological trends in nestedness and modularity of seed-dispersal networks: human impact matters. Global Ecology and Biogeography 24: 293-303

Silva FD, Assad ED, Evangelista BA. 2008. Caracterização climática do bioma Cerrado. In: Sano SM, Almeida SP, Ribeiro JF. (eds.) Cerrado: Ecologia e Flora. Vol. 1. Brasília, Embrapa Cerrados/Embrapa Informação Tecnológica. p. 71-88.

Simmons NB. 2005. Order Chiroptera. In: Wilson DE, Reeder DM. (eds.) Mammal species of the world: a taxonomic and geographic reference. 3rd. edn. Baltimore: Johns Hopkins University Press. p. 312-529.

Táxeus. 2016. Listas de espécies. <http://www.taxeus.com.br/>. 23 August 2016.

Thompson JN. 1981. Elaiosomes and fleshy fruits: phenology and selection pressures for ant-dispersed seeds. American Naturalist 117: 104-108.

Thomson FJ, Moles AT, Auld TD, Ramp D, Ren S, Kingsford RT. 2010. Chasing the unknown: predicting seed dispersal mechanisms from plant traits. Journal of Ecology 98: 1310-1318.

Tiffney BH. 2004. Vertebrate dispersal of seed plants through time. Annual Review of Ecology, Evolution, and Systematics 35: 1-29.

Tilman D. 1988. Plant strategies and the dynamics and structure of plant communities. Monographs in Population Biology 26. Princeton, Princeton University Press.

Valido A, Nogales M, Medina FM. 2003. Fleshy fruits in the diet of Canarian lizard Gallotia galloti (Lacertidae) in a xeric habitat of the island of Tenerife. Journal of Herpetology 37: 741-747.

Valido A, Olesen JM. 2007. The importance of lizards as frugivores and seed dispersers. In: Dennis AJ, Schupp EW, Green RJ, Westcott DA. (eds.) Seed dispersal: theory and its application in a changing world. Wallingford, CAB International. p. 124-147.

Walter BMT. 2001. A pesquisa botânica na vegetação do Distrito Federal, Brasil. In: Cavalcanti TB, Ramos AE. (eds.) Flora do Distrito Federal, Brasil. Vol. I. Brasília, Embrapa Recursos Genéticos e Biotecnologia. p. 59-86.

Wheelwright NT. 1985. Fruit-size, gape width, and the diets of fruit-eating birds. Ecology 66: 808-818.

Wiesbauer MB, Giehl ELH, Jarenkow JA. 2008. Padrões morfológicos de diásporos de árvores e arvoretas zoocóricas no Parque Estadual de Itapuã, RS, Brasil. Acta Botanica Brasilica 22: 425-435.

Wiki-Aves. 2016. A Enciclopédia de aves do Brasil. <http://www.wikiaves. com.br/>. 30 May 2016. 